\title{
Out of "Borrowed Space": Multi-Culturalist Discourse and Historiography in the Twenty-First Century
}

\author{
Nilgün Anadolu-Okur*
}

\begin{abstract}
Built upon contemporary discourses about centeredness and multi-culturalist approaches to history and the making of historiography, this study aims to explore the beginnings of the Afrocentric movement in the 1980s as a leading argument against the advent of Eurocentrism, and Eurocentric interpretations of historiography, civilizational agency and organization within academia in the United States. Black Power and Black Arts Movements have contributed to the formation of Black Studies programs and departments throughout the U.S. facilitating the spread of Afrocentric thought. In its demystification of Western etymology and Eurocentric arguments on universality, and historical precedence, Afrocentricity has played a fundamental role in steering culture-centered ideologies to a multitude in the Middle East, North Africa, Asia and the Far East which were particularly polarized after September 11, 2001. It has also been influential in generating conflict-resolution discourses while expanding culturalist positions in defense of civil liberties throughout the world.
\end{abstract}

Keywords: Multi-Cultural, Afrocentric, Eurocentric, Historiography, Michel Foucault, African American Discourse.

Öz: Tarihyazımına ve tarihiliğe "kendi-merkez" ağırlıklı ve "çokkültürlülük" yaklaşımları ile katılan Çağdaş söylemlerin incelenmesine dayalı bu çalışma, Avrupamerkezci ideolojilerin yaygınlaşmasına karşı Amerikan Akademisinde 1980'lerde güçlü bir alternatif geliştiren Afrikamerkezci felsefenin doğuşunu ve getirdiği önemli evreleri analiz etmeyi amaçlamaktadır. Avrupamerkezci düşünce ve Batılı etimolojilerin savunduğu evrensellik ve tarihte öngelinilirlik iddialarının çürütülmesi konusunda Afrosentrik (Afrocenticity) felsefe insanlık ve medeniyet tarihinin başlangıcına dair farklı bir bakış açııı sunmayı hedefler. Birleşik Devletlerde İnsan Hak ve Hürriyetleri hareketi sonrası ortaya çıkan Siyah Güç ve Siyah Sanatlar Hareketlerinin bir sonucu olarak üniversitelerde Siyah Etütleri departmanları ve programları kurulmuş, böylece Afrosentrik düşünce özgürce tartışıımaya başlanmıştır. Bu düşünce şekli 11 Eylül 2001 sonrasında Orta Doğu, Kuzey Afrika, Asya ve Uzak Doğu ekseninin Batı'ya karşı güçlenmesinde özellikle etkili olurken tüm dünyada yaygınlaşan çatışma karşıtı söylemlerin kabul görmesini ve insan haklarının ivedilikle savunulması yolunda kültürel farklılık düşüncesine öncelik verilmesini sağlamıştır.

Anahtar Kelimeler: Çokkültürlülük, Afrikamerkezci, Avrupamerkezci, Tarihyazımı, Michel Foucault, Afrika-Amerika Söylemi.

* Prof., Temple University, Department of African American Studies.

Correspondence: anadolu@temple.edu. Address: Gladfelter Hall, Room 826, 1115 Polett Walk, Philadelphia, PA 19122, USA

AtıfO: Anadolu-Okur, N. (2013). Out of "borrowed space": Multi-culturalist discourse and historiography in the twenty-first century. Insan \& Toplum, 3(6), 25-48.

DOI: http://dx.doi.org/10.12658/human.society.3.6.M0069 
If we have lost anything, it is our cultural centeredness; that is, we have been moved off our own platforms. This means that we cannot truly be ourselves or know our potential since we exist in a borrowed space (Asante, 1987, p. 8).

\section{Introduction}

Understanding the construction of the world's written history requires, first and foremost, a major cultural orientation for someone whose "cultural ancestry"1 does not fit into the historical parameters of Eurocentricism. For individuals raised, trained and educated outside of the Eurocentric perspective, such a predicament may present a major challenge. Eurocentricity is a legitimate culturalist position maintained by people whose cultural location is in Europe. As Yoshitaka Miike, Japanese Asia-centrist, explains, Eurocentrism is a "hegemonic universalist ideology and an ethnocentric approach to non-Western worlds and people of non-Western heritage" (Miike, 2012, p. 118). In contrast to hegemonic and universalist claims of Eurocentric discourse in historiography, the African-centered perspective offers an alternative world view about culture, ethnicity, race and religion based on pluralism without hierarchy. James Ferguson (1998) asserts that history and the writing of history (historiography) is "one way of capturing the present for the future, and alternatively of making the present more meaningful by relating it to the past." He further delineates that used properly it becomes a "dangerous tool and empowers us with a deeper perspective of the relationships in our world; misused, it can become a kind of trap from which holds us in an invented and biased past. It is for this reason, perhaps, that Herodotus was sometimes harshly attacked as the father of lies" (Ferguson, 1998, p. 7).

1 By "cultural ancestry," I do not necessarily refer to one's birthplace, because cultural adaptations, adoptions, transformations may also explain one's cultural stance. Conversely "cultural topography" is to a great extent incommensurable. As post-September 11 events have demonstrated, the Central Intelligence Agency conducted most of its operations and acted on ethnocentric inclinations, dismissing cultural, ethnic, religious variations and nuances among Muslim groups. One analyst wrote: "American decision makers have shown a need for help in isolating and understanding the complexity, weight, and relevance of culture as they consider foreign policy initiatives...l came to conclude from direct observation and some readings out of the academic field of strategic culture that America's cultural view features the notion that Americans can achieve anything anywhere including going to the moon-if they just invest enough resources." Johnson and Berrett offer a comparative analysis of Central Intelligence Agency's methods, and how cultural differences were not taken into consideration during the post-September 11 era. See, Johnson and Berrett, 2011. Although I disagree with their methods, there appears to be much truth in their assessment of some assumptions shared in general by Americans about "other" cultures. On the other hand, Edward Stewart and Milton Bennett's work offers a more satisfactory explanation. In such organizations, nurturing sensitivity and educating staff about non-Western cultures is essential. "Despite vast information resources and exposure to exotic cultures, Americans continue to overemphasize similarity and assume that other social groups have values and aspirations in line with their own." See, Stewart, \& Bennett, (1991). 
The difficulties faced by Muslims throughout the world in the chaotic aftermath of September 11 terrorist attacks elevated the meaning of "othering." Despite these newly emerging frames of references that provide deeper insight into causes of cultural alienation, African and African-American experiences naturally constitute the culminae of Afrocentric discourse as American enslavement imposed an undeniably brutal and centuries-long exploitation on generations of Africans. My goal is to analyze these emerging discourses, beginning with ancient civilizations, upon centered-ness and multi-culturalist approaches to history and making of historiography, as well as evaluating the influence of these elements on education of masses in the $21^{\text {st }}$ century. In the following, I analyze the beginnings of the Afrocentric movement in the 1980 s as a major response to the advent of both Eurocentrism, and Eurocentric interpretations of historiography, particularly in the United States. I illustrate the difficulties involved in the establishment of the Black Studies departments under the growing influence of the 1960s' Black Power and Black Arts movements in post-Civil Rights era. Then I draw my conclusions about ramifications of Euro-centered historiographical retention and its consequences on scrutiny of civil liberties throughout the world.

\section{Egypt, Sumer and Babylonia versus Greece}

Unsurprisingly critical studies on methodology and the development of history as a major discipline have almost always focused on ancient Greece rather than Africa, Egypt or Sumer. Egyptians and Sumerians preceded the Greeks; yet Eurocentrists offer no explanation for 4,500-years of relative discrepancy between the rise of Egyptian and Sumerian civilizations and the emergence of first Greek city-states around the $6^{\text {th }}$ century B.C. On the other hand, thousands of cuneiform "document tablets" that consisted of land and sea maps, records about notable events, personalities, contracts, treaties, deeds-meticulously hand-shaped by scribes from river clay and sun-baked mud-unearthed at archeological sites, tell different stories about their own origins in time. Babylonia had followed Sumer in the $23^{\text {rd }}$ century B.C. Situated at the lower half of Mesopotamia, it extended from the north of Baghdad to the Persian Gulf, in an area not far from the Euphrates and Tigris, covering 10,000 square miles. Like their predecessors, Babylonian farmers and artisans knew how to irrigate, transport water to their farms by canals, grow fruit trees, harvest and store produce. They had invented the wagon wheel and the sailboat, built homes without timber, carved stone sculptures, and facilitated a thriving trade language and communication directory through an alphabet which was uniquely their own conception. Meanwhile in Egypt, which had preceded both Sumer and Babylonia, an advanced civilization with a "centralized government system" reigned. Egyptians had invented one of the most advanced alphabets in world history, and the Golden Age of Egyptian civilization arrived after King Menes (Narmer) united the Upper and Lower Egypt in 3100 B.C. 
Whereas the accomplishments of these non-Western civilizations contribute to the growth of our information on subjugated knowledges, artifacts and documents excavated at archaeological sites clearly invalidate former axiological and epistemological premises set forth by Greeks who insist on anteriority. In An Afrocentric Manifesto Molefi K. Asante (2007) wrote, "What would the world have been like had we used Kemet and Nubia as key classical civilizations? What if Africans had been able to use Kemet and Nubia as guiding intellectual and cultural ideas? What if Africa itself had been free, unencumbered for the five hundred years that it saw European oppression in its space?" (Asante, 2007, p. 65). Whereas Africa was not allowed to prosper throughout long periods of colonization, its peoples-the youngest and the ablest-were forcefully removed from their towns and scattered across the world to be enslaved for life.

The $M a a f a^{2}$ and the Middle Passage, caused millions of African men, women and children to perish in violent seas, on remote lands and islands, under distant skies and harsh conditions, enslaved by European men and women who denied them their humanity.

Over centuries the discourse pertaining to production of knowledge continued to belong to the powerful. While Europeans continued to levy negation upon previous civilizations, the origin of "knowledge," and "knowing" was always attributed to Greeks. Despite dissemination of vast information through advanced technology, popular assumption still holds that history, logic, philosophy, mathematics and science have been "introduced" to the world initially by Greeks. On the other hand Homer, Hecataeus, Herodotus, Polybius, Strabo, Juvenal, Lycurgus, Pythagoras, Solon, Plato, Thales of Miletus and many others spent their lives seeking and recording information about distant lands, including Egypt, Sumer and Babylonia. Greek interest in foreign lands stemmed from both trade and curiosity; they sought to improve their learning on medicine, science, law, religion, philosophy, arts and architecture from Egyptian priests, and scientists. According to Egyptologist Theophile Obenga (2002) Plato, the philosopher (428-347 B.C.), and historian Diogenes Laertius, who lived in the 3rd century A.D. asserted that Thales (624-547 B.C.) sailed to Egypt in $6^{\text {th }}$ century B.C. to be educated by Egyptian priests. His rise to fame as the first Greek scientist and the philosopher who established the pre-Socratic Ionian School in Asia Minor (presentday Turkey) is thus attributed significantly to Egyptians by Greeks. Proclus (420-485 A.D.), lamblicus (250-330 A.D.) and Aetius (100 A.D.) testified that Thales spent many years in Egypt; he made experiments with water, figured out that the Nile River floods because of the Etesian winds, and measured the pyramids by their shadows having

2 Maafa is a Kiswahili term meaning "disaster," "great occurrence," and "human tragedy." It refers, in the Afrocentric paradigm, to the African Enslavement, or the "African Holocaust." The term was first introduced by Marimba Ani (See Ani, 1988, 1994). The Arabic term "al-Nakba" which is phonetically similar to "maafa" also means "great disaster," or "human tragedy." 
first observed the time when a human being's shadow is equal to his height. Moreover Thales recommended that Pythagoras travel to Egypt and learn from the priests in Memphis and Thebes (Obenga, 2002, pp. 165-179). When he returned to Miletus in his old age he had set the standards for Greek scholars who followed his example through the abundance of information they had gathered in Egypt.

However, despite the assistance Greeks received from translators and scribes, linguistic differences always constituted a barrier, and they were possibly too proud to recognize the fact that their observations indicated that they were introduced to a superior civilization. In addition to Western subjectivity, and Eurosupremacy which lay claim to advances in the sciences and humanities, speculative interpretations about cultural differences must have led to certain forms of "selectivity" causing various forms of digression in narration of their memoirs.

By his own account, Herodotus was confused about Hittite, Egyptian and other nearEastern texts which had pictographic scripts; he assumed they were all Egyptian (Harrison, 1998, p. 2). Secondly as a native of Halicarnassus (Bodrum, Turkey), Herodotus should be able to speak and write Carian fluently. Yet this was not the case, because he admitted in his Histories (Herodotus, 8.135.2) that he was unable to decipher a Carian oracle without the assistance of a translator.

Hecataeus, a statesman also from Miletus, was the first to compile in prose a geographical and demographical account of his travels that became quite an innovation for his era. He set the model for Herodotus to build an extended prose narrative. Hecataeus must have had a significant impact on Herodotus, because he was mentioned in Histories, especially when Herodotus had to disagree with him (Ferguson, 1998, p. 4). I believe the sufferings caused by the Greco-Persian clashes (499-449 B.C.) and unrelenting Persian raids on Asia Minor-ironically the key geographical region where the East meets the West-is to blame for the historical conflict between the two which sustained its damaging effects even into the $21^{\text {st }}$ century. Herodotus, a pro-Athenian was not neither so accurate nor objective in his observations which he compiled in lonic Greek. For example he states that "the naming of almost all the gods has come to Greece from Egypt" whereas he later argues that "it has come from the Barbarians" (Herodotus, Egypt, Book II, 50) by which he possibly refers to non-Greeks. Although he praised Egypt and called it a "gift of the River Nile," some of his entries about multi-faceted politics, cultures and traditions of the Mediterranean, North Africa and Western Asia may have been inconsistent for the above stated reasons and a few more, such as his failure to address the ontological and epistemological origins of the history of knowledge.

I argue that another problem lies within Orientalist discourse which attempted to extricate Egypt out of the world history. Edward W. Said stated that Egypt was the 
focal point of the relationships between Africa and Asia, between Europe and the East, between memory and actuality (Said, 1978, p. 105). Only if Egypt was to be erased from North African cultural topography, then eradication of African agency would have been made possible. Thus African epistemology, along with its axiological and ontological constituents, would be substituted with European cultural topography. Many times in history Egypt and the rest of Africa had to bear the West's organized raids and invasions on African culture, and its epistemological elements.

\section{Power, Identity and Culture}

Samuel P. Huntington (1996) argues that the distribution of cultures in the world also reflects the distribution of power. He asserts that trade may or may not follow flag, but culture almost always follows power. Expansion of European colonialism in the $19^{\text {th }}$ century and American hegemony in the $20^{\text {th }}$ century spread and validated Western culture throughout much of the contemporary world (Huntington, 1996, p. 91). Maghan Keita (2000) advances the discourse on "culture wars," which is reminiscent of Allan Bloom's (1987) classic argument on imperialistic claims of the West in his book entitled, The Closing of the American Mind. Keita (2000) argues that culture wars are about epistemological construction and reconstruction. The ideology of race led to the creation of paradigms for the construction of a culture that would exclude certain peoples. These views have come to be known as either "universal" or "canonized" to the extent that the excluded parties are regarded as being without culture, uncivilized and barbaric, untutored and illiterate, and, therefore, without intellectual capacity (Keita, 2000, p. 11).

On "exclusion," "distancing," and "othering," -European ideas put into action against African Americans throughout their enslavement- Toni Morrison (1992) argues that such attitudes provided "excellent reasons of state." She asserts that since European sources of cultural hegemony were "dispersed, and not yet valorized in the new country, the process of organizing American coherence through a distancing Africanism became the operative mode of a new cultural hegemony" (Morrison, 1992, p. 8). In The Souls of Black Folk, W. E. B. Du Bois (1903) explained the difficulty of living in a world dominated by effects of discrimination or, "othering." Following the Eurocentric trends set by Aristotle's argument on higher and lower organisms, the "scala naturae," Charles Darwin's theory of evolution convinced Europeans to deny Africans human status. In 1859 beginning with Charles Darwin's The Origins of the Species the anti-African and anti-non Western canon was set into motion. Asante remarks that social and racial motivations operated in Darwin's work as a function of the European male's presentation of self as the highest human form which becomes a self-serving formulation for the definer (Asante, 1990, pp. 21-22). 
Throughout the $19^{\text {th }}$ century Americans and Europeans took interest in world travel. Their stories led to the genre of "travel narrative" that legitimized certain plans to re-make histories based upon Eurocentric perceptions of cultures and peoples of the world. For instance, a French aristocrat and cultural attaché named Joseph Arthur Comte de Gobineau (1816-1882), recorded his memoirs as he traveled extensively in Brazil and Persia. The decline of French aristocracy had disappointed Gobineau to the extent that he devoted his mature years to the study of non-Western people. His dogmatic narrative was adopted by enthusiastic audiences in Europe as well as in the United States. In his essay titled, "An Essay on the Inequality of Human Races" (18531855), Gobineau asserted that all civilizations, including Indian, Native American, and Egyptian had been initiated by white and Aryan races whose claims on superiority of the White race was the primary factor in the development of the human species. He attributed "less-than-human" qualities to people of African descent and attempted to curtail their important contributions to civilization. Gobineau (1853) argued that "the idea of an original, clear-cut, and permanent inequality among different races is one of the oldest and most widely held opinions in the world." In his promotion of scientific racism, Gobineau further inquired, "What is the use of telling me how clever some particular savages are in guiding the plough, in spelling, or reading, when they are only repeating the lessons they have learnt?" Along with Josiah C. Nott and George Gliddon (1855) who co-authored Types of Mankind; or, Ethnological Researches, based upon the Ancient Monuments, Paintings, Sculptures, and Crania of Races, and upon their natural, Geographical, Philological, and Biblical History, Gobineau's essay stirred unprecedented hostility towards African and African American identity in the mid-1900s (Gobineau, 1853, p. 2).

Ironically the French diplomat's racist claims were severely challenged by a former slave who had escaped from the Eastern shore of Maryland. Frederick Douglass (1817-1895) concluded that the origin of all civilizations was in ancient Egypt, and that Egyptians were Africans. In 1854, in Hudson, Ohio, Frederick Douglass astonished his White audiences with his eloquent but forceful rebuttal of Gobineau's unsubstantiated claims on racial hierarchy. In his essay entitled, "The Claims of the Negro Ethnologically Considered," (1854) Douglass argued that the origin of all civilizations was in ancient Egypt, and Egyptians had the same skin color as the enslaved Africans in America. He disputed the claims of European anthropologists and ethnologists, and rejected the "sub-human category" assigned to the Black race by European scientists. When Douglass's essay was circulated around the United States, Ohio's leading newspaper, the Ohio Observer, and the National Era from Washington D.C., expressed excitement and shock. The author, once a fugitive slave, was a well-educated, "able and learned man who exhibited considerable knowledge and research" (Foner, 1999, pp. 282-297). For a self-made man who had spent most of his youth trying to flee from 
chains of slavery, accosting Gobineau's biased views was not hard at all. However for the proponents of White supremacy Douglass's identity, his former experience in slavery, and his public role as an anti-slavery agitator constituted a major setback for advancing Eurocentric claims on the purported inferiority of the African. Through his African-centered discourse on emancipation, and advocacy of equal rights for Black men and women, Frederick Douglass rose to prominence as one of the most influential orators challenging the inexorable boundaries of Western racial hierarchy, and the Jim Crowism which extended from the $19^{\text {th }}$ into the $20^{\text {th }}$ century.

\section{The African American Struggle for Civil Rights}

In America slavery was abolished in 1863. After the Civil War, despite the $13^{\text {th }}, 14^{\text {th }}$, and $15^{\text {th }}$ Amendments, and the promise of Reconstruction goals (1865-1877), the status of African Americans did not improve. Neglect, scorn, prejudice, racial hatred, segregation and discrimination continued to terrorize African Americans through the early decades of the $20^{\text {th }}$ century. Whites expected African Americans to succumb to oppression and denial of equal rights with regard to citizenship, education, voting, taxation, transportation, and societal relationships. White oppression was fostered through controlling city and state governments, school boards, armed forces, defense industries, and legislative bodies. Being an African American in the era of Jim Crow presented a precarious existence for thousands of African American men and women who endured segregation, intimidation, disrespect, imprisonment, lynching and murder instigated by advocates of white superiority groups such as the Ku Klux Klan. Of course, not all White people were guilty of such crimes, but escalating racial tension dominated American lives in the first half of the $20^{\text {th }}$ century.

Du Bois (1903) spoke of his fellow African Americans as the "seventh son born with a veil" in a world "which yields him no true self-consciousness, but only lets him see himself through the revelation of the other world." "Double-consciousness meant looking at one's self through the eyes of others, of measuring one's soul by the tape of a world that looks on in amused contempt and pity" (Du Bois, 1903/1994, p. 1-2). America was determined to cast the yoke of the world's race problem upon African Americans "two souls, two thoughts, two unreconciled strivings; two warring ideals in one dark body, whose dogged strength alone keeps it from being torn asunder." "Double-consciousness" in actuality was the expression of an existentialist quest. For a Black man the feeling of "two-ness" signified, inherently, the excruciating certainty of living with the threat of lynching, under the "veil" which separates (Du Bois, 1903/1994). As a matter of fact decades later, in 1968, activist-preacher Richard Claxton "Dick" Gregory referred to the same paradox as "the shadow that scared" him (Gregory, 1968, p. 290). 
During an international convention held by African American and African scholars in Paris, in September 1956, James Baldwin heard Aimé Césaire refer to the predicament formerly mentioned by Du Bois as "the inferiority complex," a condition which was "desired and deliberately inculcated by the colonizer (Baldwin, 1961, pp. 24-54)."³ Richard Wright, Senegalese poet Léopold Sedar Sénghor, Aimé Césaire from Martinique, and Alioune Diop, who was then the editor of Présence Africaine, were among the participants. Diop, in speaking about the relationship of politics and culture said, "the loss of vitality from which all Negro cultures were suffering was due to the fact that their political destinies were not in their hands" (Baldwin, 1961, pp. 25-26). W.E. B. Du Bois could not attend the conference, but sent a laudatory note which explained the reason for his absence: he was denied a passport by the US government. Césaire then rose from his seat and commented on the evil nature of the "cultural anarchy" which was imposed by the colonizer upon colonized nations. "The famous inferiority complex one is pleased to observe as a characteristic of the colonized is no accident but something very definitely desired and deliberately inculcated by the colonizer" (Baldwin, 1961, p. 39). Césaire asserted that there exists a dangerous relationship between the colonizer and the colonized. His words resonated profoundly among the audience: "Wherever colonization is a fact the indigenous culture begins to rot. And, among these ruins, something begins to be born which is not a culture, a subculture which is condemned to exist on the margin allowed it by European culture" (Baldwin, 1961, p. 39). The proceedings of this historical conference was compiled by James Baldwin in an essay titled "Princes and Powers," which he included in his epic work titled Nobody Knows My Name, More Notes of a Native Son (1961). Together with Fire Next Time (1963), Baldwin's essays address the racial antagonisms of the 1960s and 1970s in the U.S. and provide a comprehensive analysis concerning psychology of oppression.

While James Baldwin (1961) joined his predecessors to unveil the "masked" nature of subjugated knowledges (Foucault, 2003) and signaled the ominous warning of "fire next time", African American leaders including Dr. Martin L. King Jr., and Malcolm X-following the footsteps of Frederick Douglass and Marcus Garvey-persisted in challenging the status quo. Throughout the tumultuous years of the late 1950s and 1960s, Rosa Parks, Fannie Lou Hamer, Anne Moody, Angela Davis, Kathleen Cleaver, Huey P. Newton, Bobby Seale, Robert F. Williams, Maxwell Stanford and Amiri Baraka kept on speaking against Eurocentrism. They faced imprisonment as other voices

3 James Baldwin's "Princes and Powers" includes his pre-Civil Rights era views on culture and society. In 1957, following his return to the States Baldwin grew more articulate and maintained a centered position on African American resistance against White power in politics, race relations and American foreign policy. His sharp critique of Eurocentrism surfaced rather in the mid-Sixties. See Fire Next Time (1963), and his later works for a comprehensive analysis of the 1960s and 1970s from the vantage of Black-White relations. 
parallel to theirs were systematically eliminated from American public discourse. Throughout the second half of the $20^{\text {th }}$ century not only African American but American leadership was regularly put on trial as Americans watched in awe assassinations of President John F. Kennedy (1963), Malcolm X (1965), Martin Luther King Jr., (1968) and Senator Robert Kennedy (1968). Despite numerous set-backs, in 1954 the Brown vs. Board of Education Supreme Court decision marked the end of the "separate-but-equal" era. Segregation in education, transportation, the work place and other aspects of American life were decreed unconstitutional. However the African American struggle for equal rights continued.

The African-centered discourses of David Walker, Frederick Douglass and Martin Delaney were revived in the 1970s as manifestations of emerging Black agency and Black liberation. Throughout RAM (Revolutionary Action Movement), Black Power and Black Arts Movements, Black society kept rejecting elements of White coercion. In the 1840s the same sentiment was expressed by Frederick Douglass in his emancipatory discourse. As the 1970s drew to a close African-centered epistemology was revived in all phases of African American urban experience, including literature, arts, and aesthetics. Writers, activists and artists led by Larry Neal, Stokely Carmichael, Maya Angelou, Sonia Sanchez, Sun-Ra, Haki Madhubuti, Maulana Karenga, Eldridge Cleaver, Amiri Baraka, Angela Davis, Kathleen Cleaver, and Black Panthers pressed for Black freedom and power. Malcolm X took Black consciousness ideology to a higher level after his break with the Nation of Islam. Baraka articulated the direction of Black Nationalism, and advanced the African-centered Black liberation discourse in his poems, essays, and plays. BART/S (Black Arts Repertory Theatre) in Harlem and Spirit House in Newark brought arts to the doorsteps of the community. In Philadelphia, through efforts of PASCEP (Pan African Community Education Project) the community members were able to cooperate with faculty and students of Temple University who aimed to render education accessible to everyone. Representation of African agency entered art and aesthetics as in the creation of stylish murals (large wall paintings) along city blocks. Soon Philadelphia in Pennsylvania became one of the most decorated cities in the U.S. based upon its murals, a major art form inspired by the Black Arts Movement. Since then more elaborate and larger representations of Black urban life have been painted on walls around city blocks, in neighborhoods, parks and on various structural surfaces.

\section{Michel Foucault, Genealogy and Desubjugating Knowledges}

For my study, the most striking aspect of an African-centered perspective involves the investigation of the global divide between Western and non-Western cultures which seems to grow deeper in the 21st century. During the Gulf War the Moroccan author 
Fatima Mernissi (1992) compared Western forces to a "spider spinning its web" in North Africa. Instigating fear, confusion and even "the most incomprehensible" ("ajib" in Arabic) bombing of Baghdad generated a great deal of opposition in North African cities from Morocco to Algiers, Tunis, Cairo, Damascus, and Rabat. Local people chanted: "Ma sa'alunash! Ma sa'alunash! Al-qarar qararna! Ma sa'alunash! Ma sa'alunash!" (They didn't consult us! They didn't consult us! The decision belongs to us! They didn't consult us! They didn't consult us!) (Mernissi, 1992, pp. 14-15). Certainly Mernissi recognizes the power of the West, as well as its shortcomings. She asserts that in addition to serious flaws in understanding cultural differences, the West capitalizes on mega plans about delivering instant democracy to non-Western nations. However, she believes that the West is unable to recognize that such plans are doomed to fail. The Gulf War (19901991) and the Iraqi War (2003-2011) were fought to establish Western-style political regimes in order to control non-Western nations in the region. Mernissi argues that as Westerners tried hard to demolish fanaticism and fundamentalism in such countries they became fanatics themselves. "But the West and its cameras, focused behind another hijab and on other fears, sees in the Arab world only the dawn of obscurantist fanaticism" (Mernissi 1992, p. 16). She refuses to put up with European aspirations and the desire to control and colonize other people's histories, because colonialist tendencies always aim to subjugate the legacy of "other" knowledges. Mernissi states that "in the gharb (the Arabic word for the "West") everything is engulfed in darkness." The gharb represents "the most incomprehensible," and what is "frightening"; it is "the territory of the strange, the foreign - the gharib." It is not possible to "see" in darkness; therefore a person has "to rely on the other senses to make out what is moving, what might be dangerous" (Mernissi, 1992, p. 13).

In 1976, Michel Foucault (1926-1984) opened his famous series of lectures in "Society Must be Defended" with a discussion of the "insurrection of subjugated knowledges" (Foucault, 2003, p. 7). He described subjugated knowledges as "masked" and "buried historical contents in functional coherences of formal systematizations," or "disqualified nonconceptual knowledges," and "hierarchically inferior knowledges." Peripherialized, de-centered, dismissed and disregarded so long, the accumulated wealth of world's resources of civilizational knowledges and their once glorious agents were being silenced by dominant monopolies over centuries. But its demise was near. "Another history now begins to challenge it: the counterhistory of dark servitude and forfeiture. This is the counterhistory of prophecy and promise, the counterhistory of the secret knowledge that has to be rediscovered and deciphered (Foucault, 1976, p. 73).

Foucault proposed to desubjugate historical knowledges as explained in his theory of genealogy. He wanted to promote marginalized knowledges and hearten masses to object, protest, resist, and strive to challenge the "unitary, formal and scientific theoretical discourse" (Foucault, 2003, p. 10). Mernissi's depiction of fear spread by 
the gharb is firmly articulated in Foucault's remarks about the formulation of history as "a unitary sovereignty that was legitimate, uninterrupted, and dazzling" (Foucault, 2003, p. 10). He defines history as the "discourse of power, the discourse of the obligations power uses to subjugate," in order "to fascinate, terrorize, and immobilize, that guarantee order" (Foucault, 2003, p. 68).

I argue that from nations to cultures, religions and races, Western epistemology continues to impose itself upon non-Western cultures. Asante asserts that "much of history is laced with hostility toward Africa" (Asante, 1990, p. 158). Afrocentricity as a philosophical stance originated from African people's resistance to cultural hegemony. As a social theory it contends "dislocation, disorientation, and mental enslavement of African people is a function of White racial hegemony" (Asante, 2007). Black Studies programs in the U.S. grew out of the Black Nationalist political tradition. Thus, the Afrocentric idea as a social theory bears the revolutionary spirit of the Black Studies programs. Asante himself was a member of the student organization at UCLA Berkeley; he participated in the student protest movements and later compiled his views on Black social mobilization in his book titled, An Afrocentric Manifesto (Asante, 2007, p. 23).

In 1989 Afrocentric thought was advanced further when the nation's first doctoral program was established at Temple University's African American Studies Department in Philadelphia, Pennsylvania. Asante, as one of the founders, and the first chairman of the department became the major advocate of Afrocentric philosophy. In Afrocentricity (1988) Asante outlined the premises of an African-centered cultural consciousness for African American people. His theoretical approach had riveted, in its origins, the difficulty of living in the midst of a racially divided and highly polarized nation. Thirty years after the legendary bus boycott initiated by Mrs. Rosa Parks in Montgomery, Alabama (1955-1956), most African Americans were still marginalized, pushed to the fringes of poverty, and forced to live in a new Jim Crow era. In Decolonising the African Mind Chinweizu (1978) asserted that overthrowing the colonial inheritance required African Americans "to reform everything" to define their objectives, set their own standards, and pick their own heroes from among those who outstandingly serve their own interests" (Chinweizu, 1987, p. 9). The Afrocentric idea rose on the foundation laid by Africancentered philosophy in reaction to European domination and mobilization based upon subjugated histories of Black people. Its primary focus involved an educational reform which included establishing a school curriculum for children of African descent.

\section{Multi-Culturalism: Discourse and History}

In educating one's self the first step is about recognition of one's teacher. This becomes particularly important in times when ownership of true knowledge is denied to a particular people. Thus "ownership" and "agency" become major attributes in understanding 
the significance of a centered approach where Africans are viewed, in Molefi K. Asante's (1999) words, "not in a junior but senior light." In The Painful Demise of Eurocentrism, Asante argued against Mary Lefkowitz's (1996) Not Out of Africa: How "Afrocentrism" Became An Excuse To Teach Myth As History for the same reason. Lefkowitz (1996) asserted that her goal was "to show why Afrocentric notions of antiquity, even though unhistorical, have seemed plausible to many intelligent people" (Lefkowitz, 1996, p. xiii-ix). She stated that the uncertainty was caused by the present intellectual climate, blaming the academicians whom she believed treated history as a "form of fiction" that can and should be written differently by each nation or ethnic group. Paradoxically Lefkowitz's analysis accounts for the ominous situation Western academia is presently caught in. "How could anyone suppose that the ancient Greeks were not the authors of their own philosophy and scientific theory?" (Lefkowitz, 1996, pp. xiii-ix).

On the other hand Martin Bernal (1987) in Black Athena: The Afro-Asiatic Roots of Classical Civilization refuted Herodotus's Histories, and linked the origin of classical civilization with Afro-Asiatic cultures. Many historians were taught to regard Herodotus as "the father of history." Yet Bernal firmly argued that even those who followed Plutarch and regarded him as the "father of lies," could hardly maintain that Herodotus was lying about the existence of such chronicles (Bernal, 1987, p. 75).

Not far from Babylonia, in Saqqara, the discovery of "pyramid texts," dating from 3000 B.C., informs us that Egyptians began contributing to our collective knowledge much earlier than Greeks. Papyruses and wall paintings contained scores of lines of hieroglyphic texts about multi-faceted aspects of Egyptian civilization and culture, including spirituality and symbolism, rituals, history, astronomy, particulars about secular life, music, art, aesthetics, morals, ethics, festivals, and philosophical thoughts of wise men and women about life and after-life. Historical data about their various achievements were recorded on thousands of ostraka, which were probably the earliest prototypes of today's electronic notepads. Archaeologists carefully unearthed thousands of small limestone slabs, and clay fragments in Deir-al-Medina. ${ }^{4}$ Used for maps, sketch-making, drawing, mathematical calculations, and list-making these artifacts bear out the fact that Egyptians, like their neighbors Sumerians, placed their mark on historiography long before Greeks did (Bongioanni \& Croce, 2001, pp. 526-535).

Deir-al-Medina is a small town in the Valley of the Kings, on the west bank of the River Nile, close to Karnak. The townspeople were artists, craftsmen and skillful professionals who worked in the construction of royal tombs of Biban al-Moluk. Thousands of pieces of ostraka excavated at the site inform us about the daily activities of its residents. Besides chronicling the townspeople's life, the decorated ostraka included pictures of the human body from the Nineteenth and Twentieth Dynasties, (1291-1075 B.C.) created by professional artists. Several pieces depicted pharaohs, and particularly the reign of Rameses VI (143-1135 B.C.). This flourishing community of artists, artisans and their youthful apprentices lasted about 450 years. For Egyptian papyruses, ostraka, texts, drawings and artists see Bongioanni, \& Croce (2001). 
Hence, epistemologically Greeks are not the sui generis producers of "history" or its methodology. The chronological incongruity defeats prior arguments on Greeks' historical and civilizational precedence. An inquiry into the diplomatic relations among Egyptian, Sumerian, Babylonian, Hittite and Greek people maintains that Greek students were sent to Egypt and other countries to be trained in academies of higher learning. Anaximander, and his student Thales of Miletus (Balat, Aydin in Turkey), whom the Europeans called "the Father of Philosophy," also traveled abroad. Thales was extremely skillful in utilizing geometrical formulas to address philosophical issues; reportedly he had learned his famous theorem from Babylonians while studying mathematics in their capital city.

Pythagoras, Isocrates, Aristotle, Hecataeus and Herodotus who was called the "Father of History," all traveled to Egypt, Persia, Babylonia and Crimea to gather information about religion, secular life, cultural characteristics, norms and traditions in these countries (Brown, 1965, p. 50). Herodotus mentions that throughout his travels in Anatolia he interviewed Phrygians, visited Gordium (Eskisehir) and Iconium (Konya), both historic cities in present-day Turkey. He wrote that during his trip to Babylonia he consulted priests and even met a Crimean King. Ironically Herodotus referred to his hosts as "barbarians." Nevertheless he admitted that they had advanced skills in writing and accumulating information. Histories depict, in nine parts, significant details about Egypt including the Nile, its surroundings, as well as the Great Pyramid of Giza. However it is in Books Two and Three that Herodotus captures the most comprehensive account of a highly civilized nation, revealing his observations in Egyptian cities and along the Nile. Unquestionably Histories (circa. 440 B.C.) remains the major accomplishment of a Greek historian confirming Egypt's relationship with neighboring countries, and achievements of a sophisticated legislative and executive power much earlier than Greek systems were instituted. It is fascinating that in his foreword Herodotus saw himself in the light of posterity and reminded his reader that his book is about exchange of valuable information among nations. "This is the showing-forth of the inquiry of Herodotus of Halicarnassus, so that neither what has come to be from man in time might become faded, nor that great and wondrous deeds, those shown forth by Greeks and those by barbarians, might be without their glory; and together with all this, also through what cause they warred with each other" (Greene, 1985, p. 33).

Throughout the final decades of the $20^{\text {th }}$ century Eurocentric discussions on "invention of historiography" quickly boiled over to the arguments of ownership and agency. Molefi K. Asante (1999) claimed that Mary Lefkowitz almost dismissed Herodotus's Histories simply because he had written that the impact of Egyptian culture and civilization on Greeks were phenomenal. He argued that "Eurocentric arrogance expressed as a white supremacy view" was at the heart of mistrust and injustice in the world, and that resistance to Afrocentricity was founded on a White supremacist view of 
Eurocentrism. He was surprised that even Black critics were using White supremacy to attack Afrocentricity (Asante, 1999, p. ix). He continued to criticize Diane Ravitch's (1990) objection to multicultural education, who manifestly argued that there was not enough time to teach Afrocentric curricular items in a given school year. In return Asante (1991) stated that there is space for Eurocentrism in a multicultural enterprise so long as it does not parade as universal, or does not force its way because Afrocentricity "does not seek to replace Eurocentricity" in its "arrogant disregard for other cultures" (Asante, 1991, pp. 276-272).

Naturally these debates brought forth new challenges in the $21^{\text {st }}$ century. Currently the major problem with Eurocentrism lies in its reductionist attitude toward earlier civilizations who have been contributing to the rise of systematic historical thought as recorded by Greeks. The other problem that I perceive is the recurrence of what I call "peripheral essentialism" certainly an elitist position within Eurocentrism. This attitude is based upon exclusion and elitism, particularly via "othering," in order to "isolate" and "exclude" cultures and religions of the Orient, the Near East, the Middle East, the Far East, Africa, Asia, parts of Central and South America, with the inclusion of Native American, Eskimo, and Alaskan people. Advocates of peripheral essentialism constitute only a minority within seven billion people who inhabit our world. Yet it is a hegemonic position legitimizing peripherality, and assigning a peripheral, marginal, and lower status to nations and societies that do not demonstrate Western characteristics. As Karl Popper (1957) argued in Poverty of Historicism, the origins of hegemonic attitude lie in the essentialist and elitist policies of the West towards multi-dimensional perspectives that define other cultures.

Ultimately questions triggered by this epistemological inquiry involve whether "knowledge" in any form did not exist before Herodotus, and whether our information about the origin of "knowledge" is whole, or fractioned. We also need to question if we are being educated at someone else's academy, in a "borrowed space." Whose information do we receive? Our education in history is incomplete and abridged unless we are fully informed about counter histories, other civilizations and cultures which deviate from the Eurocentric pattern. Pluralism without hierarchy is one of the gifts of Africa-centered learning to multi-cultural education; it facilitates diversity planning in schools, and aims to focus on multi-faceted world views, rather than fostering the development of a monolithic society based upon a singular world-view. From a philosophical standpoint Afrocentricity represents an alternative mode of thinking and maintains the possibility of safeguarding multicultural education beyond the tutelage of Lefkowitz and Ravitch, and others within the Eurocentric canon. Eurocentrism is likely to fail unless it finds radical solutions to address social, political, and economic problems pertaining to differences in culture, race, religion, gender and age-based discrimination throughout the world. 


\section{Convergent Paths and Cultural Re-Centering}

The factors that facilitate centered approaches in order to desubjugate knowledges and deconstruct the influence of Eurocentric power sources involve a complex interplay of scholarly considerations. First are the historical factors that require us to look at activist agendas that aim to deal with supremacist visions in an increasingly diversified world. Next, there is the existentialist question of why and how "centeredness" involves the robust expression of one's aspirations, of self-confidence and autonomy, within one's own ethnic, racial or religious group. Since the beginning of the $21^{\text {st }}$ century there have been numerous developments on convergent paths to assess and structuralize a multidimensional framework of reference based upon intercultural communication and research. In the following I explore the influences of these developments on our collective learning experience.

In How Does it Feel To Be a Problem? Moustafa Bayoumi (2009) interviewed seven individuals from Brooklyn's Arab community in New York. The respondents re-told their post-9/11 experiences, and commented on several instances of "othering" while they were being profiled as "suspicious people," regardless of their Christian and Muslim backgrounds. Bayoumi stated that while profiling other groups was "officially and legally un-American, profiling Arabs and Muslims made good national-security sense" (Bayoumi, 2009, p. 4).

What parameters are used to define dimensions of religious or racial profiling? To respond to this inquiry a self-conscious effort is needed. If the world is analyzed from one's own center rather than from someone else's center agency is not lost. Asante (2007) remarks that an Afrocentrist interprets the world from the perspective of African agency (2007, p. 22). Following the major tragedies that occurred on American soil, such as the attacks on September 11, 2001, and the Boston Marathon bombings in April, 2013, any Muslim, regardless of his location- whether in Brooklyn, Jerusalem, Montreal, Philadelphia, Cairo, Damascus, Zurich or Istanbul-interprets the world from the standpoint of Muslim agency in reference to matters of religious and cultural signification. In the new order racial, ethnic and religious make-ups manifest significant thresholds against rigid parameters of identification set by Eurocentrism. Historically African Americans, and Africans have been conscious of such constrictions; they have been oppressed and discriminated since the $1600 \mathrm{~s}$. It is important to re-iterate here that Eurocentrism is an ethnocentric approach and universalist ideology towards people of the non-Western world, whereas Eurocentricity is a particularist philosophy about culture and people of European heritage. Asante (2010) stated that "Afrocentricity was not the counterpoint to Eurocentricity, but a particular perspective for analysis that did not seek to occupy all space and time as Eurocentrism has often done" (Asante, 2010, p. 49). 
In 2012 Yoshitaka Miike interviewed Molefi K. Asante on intercultural communication and the significance of promoting multi-culturalist historiography. During the discussion, Diane Ravitch's views on multi-culturalism came up as a point of negation for both scholars. Earlier Ravitch had argued that White culture, and its historical roots have to "remain hegemonic with all other cultures under an overarching White cultural domination" (Asante, 1991, p. 272). The idea of White cultural domination is objectionable in any study of human history which holds that life began in Africa 2,500,000 years before. Before Asante many scholars had already challenged the legitimacy of White cultural hegemony. Léopold S. Senghor (1988), the Senegalese author and critic, asserted that since the beginning of human history and up to the Later Paleolithic Age of 40,000 years ago, Africa had remained at the forefront of human civilization. Moreover he concluded that Africa's primacy continued since the fourth millennium B.C. (see Sénghor, 1992, p. xi). In early 1950s Cheikh Anta Diop announced that "the civilizations of the Nile Delta were Negro-African ones" (Diop, 1974). Two years later, in an essay he compiled for the inaugural issue of the journal of the Association des Etudiants du Rassemblement Democratique Africaine, Diop reiterated his earlier conviction. In 1954, in Nations Nègres et Culture in Paris, it was Diop who declared that African history is anterior to all other histories because the earliest records of human presence were first discovered in Africa. In his later works he continued to assert that the Nile Valley was the cradle of all Black African populations, both ancient and modern, and Africa had civilized the rest of humanity (Diouf, \& Mbodj, 1992, p. 121). For Diop raising international awareness about Africa's primacy was crucial. Against White historicism's claims of precedence and anteriority, emphasis on African historicism was strategically essential. Promoting the legitimacy of Africa's anterior role would help defeat Universalism and Western cultural essentialism. It could also streamline clichéd definitions such as "structuralism" "neo-colonialism" and "post-colonialism." Fundamentally, Diop's radical assessment towards desubjugating African knowledges revolutionized all established patterns of thought. He pioneered the movement about reversing commonly-held positions on linguistic, scientific, sociological, historical and political supremacy of the West. Consequently, one of the most intriguing questions during the last decades of the past century involved the genealogy of knowledge: If civilizations were started by non-Greek cultures, then who were the makers of history? The following may provide useful answers.

Egyptologist Theophile Obenga is cited among the group of scholars who refuse to concur with Eurocentrism's peripheral essentialism and its promotion of "othering." Obenga stressed that the "contemporaneity of African history comes down to focusing clearly on the fact that the Africans will truly be liberated not by oblivion but by their history which emerges from and is blended in with universal history" (Jewsiewicki, 1992, p. 106). Molefi K. Asante (2012) stressed that Eurocentrism is soon go- 
ing to be extinguished in a self-deprecating spiral which it started by the creation of anti-egalitarian, anti-African, anti-Asian, and anti-Latino forms of rhetoric that have trapped the West in a self-referential language of dominance. "We must, in the end, avoid all constructions that inherently sideline Asian and African people. In fact, there is nothing in the so-called collective cultures of Africa and Asia that reduce other people to sub-cultures and sub-humans" (Asante, 2012, pp. 65-80). Asante further argues that with their critical cosmopolitan language, modern sociologists attempt to account for the seduction present in Western hegemonic notions of communication, and such subjectivity is the source of ideas of "othering." As a matter of fact, this attitude was at the heart of German mobilization for the Holocaust, confirming Hitler's concept of Untermenschen, because it too was sanctified with ascription of difference (Asante, 2012, pp. 65-80). He stresses the fact that Imhotep (2700 B.C.), Ptahhotep (2114 B.C.), Kagemni (2300 B.C.), Akhenaten (1300 B.C.), Buddha and Kung Fu Tzu (around 563 B.C.) all lived much earlier than the famous Greeks in history. Yet neither these individuals nor their significant contributions to modern philosophy are as celebrated as Homer's (800 B.C.), an epic poet whose major accomplishment was to travel abroad and narrate his observations.

One of the major proponents of Afrocentric learning in the U.S. is Maulana Karenga, scholar and activist founder of the US organization in Los Angeles, who first proposed training in traditional African value system for African American society. He advocated "Kawaida," which in Kiswahili means, "that which is customary, or traditionally adhered to, by Black people" (Baraka, 1972, p. 12). As a paradigm of social change, Kawaida relied on Seven Principles of Nationhood, the "Nguzo Saba." These principles were Umoja (unity); Kujichagulia (self-determination); Ujima (collective work and responsibility); Ujamaa (cooperative economics); Nia (purpose); Kuumba (creativity) and Imani (faith). In 1967 poet, playwright and activist Amiri Baraka adopted Kawaida as a philosophical attribute of learning. He taught Kawaida at BART/S (Black Arts Repertory Theatre/School) in Harlem as a basic component of his lectures on African discourse, and African self-determination. Kawaida's seven principles were considered "the spine and total philosophy of the US organization." Baraka referred to them as "the ten commandments" that are "fulfilled by the initial need of blackness for unity, that is, oneness" (Baraka, 1972, p. 13). Meanwhile Maulana Karenga introduced Kwanzaa as the African celebration of the New Year, whose symbols of harvest, fruits, and lit candles represented African epic memory, African heritage, and centeredness in one's own cultural context.

Among contemporary Afrocentricists Kariamu Welsh's work is a stellar example of a scholar/artist/choreographer's preoccupation with African historiography. Welsh asserts that "through associative symbols new energies are created... which can sustain and manifest artistic renditions." Umfundalai, (meaning "the essential" in Kiswahili) 
both as paradigm and choreography represents the impact of African philosophy on European thought (She, 1973, pp. 7-9). ${ }^{5}$ Welsh-Asante does not overlook the fact that interactions between African philosophical paradigms and European-derived forms inevitably generated new concepts in art and aesthetics. Yet African historiography is not a derivative of European historiography. African-centered perspectives in African American theater have made Black drama a unique art form, differing in many aspects from European drama, which has also not been primarily a derivative of American theater (Anadolu-Okur, 1997, p. xiv).

Yoshitaka Miike's (2012) Asia-centric historiography focuses on methodology and development of "history" as a discipline from the standpoint of Asian people. His views help advance arguments against Eurocentrism and its long-standing efforts to historicize historiography solely from the perspective of Western intellectual heritage. Miike also asserts that despite the way Afrocentricity is perceived by Whites there is no danger of Eurocentrism being replaced by Asiacentric or Afrocentric knowledge. Contrary to what Asante expounds, Miike believes that due to the highly privileged status of Eurocentric knowledge and its institutional infrastructures all over the world, there is no sign that studying and learning Afrocentric and Asiacentric knowledge is going to erase European intellectual traditions in future. Essentially, through de-centralizing the "white privilege" in historiography of the modern age, Afrocentric methodology has played a greater role particularly by re-assessing educational policies in schools. Building self-confidence and pride in African American youth through advocacy of non-hierarchical diversity planning has been one of its accomplishments.

In African American epistemology reverence for dialogue is represented by the power of "nommo" (the "spoken word" or "utterance," in Kiswahili) which is the symbol of truth, justice, and rightfulness. Nommo is believed to radiate transformative energy; it generates "message transmittal," "knowing one's self," "teaching and learning," "re-claiming the past and the future," and consequently "commanding the present." In speech, discourse and orature-making expression of African agency is materialized by engaging nommo. Through negating Eurocentrism, one asserts the prevalence of African agency, particularly in matters that relate to people of African descent. Although there is not one specific method, and overall human circumstances determine how a person utilizes the spoken word, Nommo's "kanuni" ("the principles") facilitate coordination of African American discourse in a methodical way. The eleven kanuni remain at the heart of Afrocentric critical inquiry in discourse, and provide

5 For Umfundalai see Kariamu Welsh-Asante, (1973). The interaction between African philosophical paradigms and European-derived forms generated new concepts in art and aesthetics. With this frame of reference, however, it must be recognized that African historiography is not a derivative of European historiography. For African-centered methodology on African American discourse and its aesthetic components, see Anadolu-Okur, (1997). 
infinite possibilities to assess the limits of Eurocentric negations. Essentially "kanuni" refers to the direction of historiographical methodology in maintaining the continuity of Africa-centered discourse, and it consists of the following:

First, it reflects African people's focus on historical consciousness; it is empowered to transcend Eurocentric negations on questions of ethics, values, morality, equality, history, justice, and truth. It is cognizant of the causes of social crisis and provides insight for racial, religious and economic bias. It embraces a grand mission, which is about humanizing the world. It aims to foster human relationships, and eliminates stereotypes; re-defines resistance, liberation and action for the particular people. It is center-oriented; locates its own audience, and identifies arts, aesthetics, songs, motifs, legends, and sagas which define African cosmology, epistemology and axiology. It determines the social and political setting for African modes of action. It emphasizes Ma'at symbol of harmony, truth, justice and order in Egyptian cosmology which is depicted during the Old Kingdom 2649-2150 B.C. as a seated goddess with a cobra on her forehead and the tall curved plume on her head) which represented the First Order, perfection and immutability, the ideal organization of the cosmos and its creatures in Egypt. In modern perception, kanuni is about envisioning the African future through concepts of unity, equality, justice and harmony. The African-centered paradigm has strong effects on challenging questions of value, claims of universalism, "subjectivity" versus "objectivity" and the discourses that originate from clash of Western and non-Western ideologies (Anadolu-Okur, 1997, pp. 3-4).

But what are the responsibilities of historians in making historiography? Bernard Lewis (2004) states that historians' responsibilities reach beyond personal involvement, and commitments. "We are all...the children of our time and place, with loyalties, or at least predispositions, determined by country, race, gender, religion, ideology, and economic, social and cultural background." First and foremost, Lewis emphasizes "motive," and "just cause." Secondly, he argues that the historian "owes it to himself and to his readers...to be objective...to make corrections, to present different aspects of a problem, and the different sides to a dispute in such a way as to allow the reader to form his own judgment" (Lewis, 2004, p. 9). Lewis argues that the historian should not "prejudge issues and predetermine results by the arbitrary definition of topic and selection of evidence, and the use of emotionally charged or biased language" (Lewis, 2004, pp. 60-65). ${ }^{6}$

Not only historians but statesmen and diplomats too need to act responsibly in the creation of coherence in historiography. Francis Fukuyama (2006) warns against

6 This work is a compilation of the most significant essays of Bernard Lewis since 1949 on Middle Eastern countries, and their relationships with Europeans. For Lewis's particular attention to Turks and Turkish history, see Lewis (2004, pp. 421-429). 
the dangers of promoting biased opinions and cultural polarization among nations. The post-9/11 developments have taught American policy-makers serious lessons beyond authoritarianism and its critical influence on American foreign policy: "What the United States needs today is centrist policy that combines some of the toughmindedness of the right with greater realism about the way the world works beyond America's shores, and how it perceives our behavior" (Fukuyama, 2006, pp. xvi-xvii). Fukuyama suggests that mutual understanding has to command international relations. Fatima Mernissi, on the other hand, draws attention to the pervasive influence of Eurocentrism. "We must understand in order not to go under....It is not up to the foreign West to understand us; it is up to us to understand the West. We are well equipped for the job: millions of Arabs speak the languages of the West" (Mernissi, 1992, pp. 13-22). On the Arab-Israeli conflict, which has led the one of the deadliest territorial disputes in human history, the Lebanese scholar Tony Maalouf (2003) wrote, "The biblical legacy of Arabs and Jews has the potential to reconcile both antagonistic parties under the Abrahamic umbrella and to offer the hope of the gospel of peace in an area tyrannized by war" (Maalouf, 2003, p. 39).

\section{Concluding Remarks}

In this study I have proposed that a multi-culturalist approach be used within academia to provide alternative responses to Eurocentrism's dominance in the study of historiography. There is no reason why African and Asian-centered theories, be they Turko-centered or Korea-centered perspectives, on history and knowledge should not be recognized as prominent elements of historiography and discourse. Ideologically oriented epistemologies should be replaced by a celebration of "centeredness" and agency of particular people with attention to distinct cultural patterns. To accomplish this task a lexical, axiological and cosmological refinement is needed. What matters is whose cultural topography and intellectual parameters are taken into consideration. "Borrowed space" accounts for poverty in historicism, and prioritizing someone else's center, rather than one's own. Under growing threat of universalism, globalism and consumerism, the fundamental thrust of any philosophical theory outside the West should be about maintaining accountable agency, and re-defining its own cultural center in all matters that are relevant to the group's epistemological reality and axiological concerns. "Receivership" is objectionable; the struggle to uncover the truth often consumes the inquisitive mind.

Conversely, it is no longer in the best interest of any state to isolate minority groups by fostering peripheral essentialism. Multi-culturalist historiography suggests alternative methods to promote stability and peace among peoples of the world. Ma'at, the Egyptian philosophical operative of propriety and governance attests to the value 
of rightful co-existence in an increasingly divergent and multi-cultural world (see Anadolu-Okur, 1995, pp. 139-151). As new tides of challenges signal worldwide distress, not only academia but national leaders need to act responsibly. Rapprochement requires eliminating reasons that lead to cultural wars which tend to ignite religious, racial and territorial confrontations among nations. The more the privilege, the greater the responsibility.

\section{References}

Anadolu-Okur, N. (1995). Ma'at, Afrocentricity and the critique of African American drama. In D. Zeigler (Ed.), Molefi Kete Asante and Afrocentricity, in praise and criticism (pp. 139-151). Nashville, TN: James C. Winston.

Anadolu-Okur, N. (1997). Contemporary African American theater: Afrocentricity in the works of Larry Neal, Amiri Baraka, and Charles Fuller. New York, \& London: Garland Publishing.

Ani, M. (1988). Let the circle be unbroken: The implications of African spirituality in the diaspora. New York, NY: Nkonimfo.

Ani, M. (1994). Yurugu: An African-centered critique of European cultural thought and behavior. Trenton, NJ: Africa World.

Asante, M. K. (1987). The afrocentric idea. Philadelphia, PA: Temple University.

Asante, M. K. (1988). Afrocentricity. Trenton, NJ: Africa World.

Asante, M. K. (1990). Kemet, Afrocentricity, and knowledge. Trenton, NJ: Africa World Press.

Asante, M. K. (Spring, 1991). Multiculturalism: An exchange. The American Scholar, 60(2), 267-272.

Asante, M. K. (1999). The painful demise of Eurocentrism: An afrocentric response to critics. Trenton, NJ: Africa World.

Asante, M. K. (2007). An afrocentric manifesto: Toward an African renaissance. Malden, MA: Polity.

Asante, M. K. (2010). Afrocentricity and Africalogy: Theory and practice in the discipline. In J. R. Davidson (Ed.), African American studies (pp. 35-52). Edinburgh, Scotland: Edinburgh University Press.

Asante, M. K., \& Miike, Y. (2012). Harmony without uniformity: An Asiacentric worldview and its communicative implications. In L. A. Samovar, R. E. Porter, \& E. R. McDaniel (Ed.), Intercultural communication: A reader (pp. 65-80). Boston, MA: Wadsworth Cengage Learning.

Asante, M. K., Miike, Y., \& Yen, J. (Ed.). (2013). The global intercultural communication reader (2nd ed.). New York, NY: Routledge.

Baldwin, J. (1961). Princes and powers. In Nobody knows my name, more notes of a native son (pp. 13-56). New York, NY: Dell.

Baldwin, J. (1963). Fire next time. New York, NY: Dial Press.

Baraka, A. (1972). 7 principles of US and Maulana Karenga and the need for a Black value system. In Kawaida studies: The new nationalism (pp. 9-12). Chicago, IL: Third World Press.

Bayoumi, M. (2009). How does it feel to be a problem?: Being young and Arab in America. New York, NY: Penguin. Bernal, M. (1987). Black Athena: The Afro-Asiatic roots of classical civilizations. New Brunswick, NJ: Rutgers UP. Bloom, A. (1987). The closing of the American mind. New York, NY: Simon and Schuster.

Bongioanni, A., \& Croce, M. S. (Ed.). (2001). The illustrated guide to the Egyptian museum in Cairo. Cairo, Egypt: American University in Cairo.

Brown, T. ( Ed.). (1965). Ancient Greece. New York, NY: Free Press. 
Chinweizu. (1987). Decolonising the African mind. Lagos, Nigeria: Pero Press.

Diop, C. A. (1974). The African origin of civilization: myth or reality. Westport, CT: Lawrence Hill.

Diouf, M., \& Mbodj, M. (1992). The shadow of Cheikh Anta Diop. In V. Y. Mudimbe (Ed.), The surreptitious speech: Présence Africainé and the politics of otherness $1947-1987$ (pp. 118-135). Chicago, IL: University of Chicago.

Douglass, F. (1854, July 12). The claims of the Negro ethnologically considered: An address before the literary societies of Western Reserve College, at commencement. Pamphlet. Rochester, NY: Lee, Mann and Co.

Du Bois, W. E. B. (1903/1994). The souls of black folk (4 $4^{\text {th }}$ ed.). Mineola, NY: Dover Publications.

Ferguson, J. (1998). From Hecataeus to Herodotus: The expansion of the Greek world-view. Journey to the west: Essays in history, politics and culture, 7. Retrieved September 23, 2013 from http://www.international-relations. com/History/Herodotus.pdf.

Foner, P. S. (1999). Frederick Douglass, selected speeches and writings. Chicago, IL: Lawrence Hill.

Foucault, M. (2003). "Society must be defended" lectures at the Collège de France 1975-1976. New York: Picador.

Fukuyama, F. (2006). America at the crossroads: Democracy, power, and the neoconservative legacy. New Haven, $\mathrm{CT}$ : Yale University.

Gobineau, A. (1853). An essay on the inequality of the human races. London, England: William Heinemann.

Greene, D. (1985). Herodotus. The history (Trans. Book One). Chicago, IL: University of Chicago.

Gregory, D. (1968). The shadow that scares me. New York, NY: Pocket Books.

Harrison, T. (1998). Herodotus's conception of foreign languages. Histos. Retrieved September 20, 2013 from http://www.dur.ac.uk/Classics/histos/1998/harrison.htm.

Herodotus. (n. d.). Histories, Book II, 49-51.

Herodotus. (1985). The history (Trans. D. Greene) (Book One). Chicago, IL: The University of Chicago Press.

Huntington, S. P. (1996). The clash of civilizations and the remaking of world order. New York, NY: Simon and Schuster.

Jewsiewicki, B. (1992). Présence Africaine as historiography: Historicity of societies and specificity of Black African culture. In V. Y. Mudimbe (Ed.), The surreptitious speech: Présence Africainé and the politics of otherness 1947-1987 (pp. 95-117). Chicago, IL: University of Chicago.

Johnson, J. L., \& Berrett, M. T. (2011). Cultural topography: A new research tool for intelligence analysis (extracts). Studies in Intelligence, 55(2), 1-22.

Karenga, M. (2010). Introduction to Black Studies (4 ${ }^{\text {th }}$ ed.). Los Angeles, CA: University of Sankore Press.

Keita, M. (2000). Race and the writing of history: Riddling the sphinx. New York, NY: Oxford University.

Lefkowitz, M. (1996). Not out of Africa: How "Afrocentrism" became an excuse to teach myth as history. New York, NY: Basic Books.

Lewis, B. (2004). History writing and national revival in Turkey. In From Babel to dragomans, interpreting the Middle East (pp. 421-429). New York, NY: Oxford University.

Maalouf, T. (2003). Arabs in the shadow of Israel: The unfolding of God's prophetic plan for Ishmael's line. Grand Rapids, MI: Kregel.

Mernissi, F. (1992). Islam and democracy: Fear of the modern world (Trans. M. J. Lakeland). Reading, MA: Addison Wesley.

Miike, Y. (2012). Cultural traditions and communication theory: Clarifying the Asiacentric paradigm. China Media Research, 8(3), 3-5.

Morrison, T. (1992). Playing in the dark: Whiteness and the literary imagination. Cambridge, MA: Harvard University.

Nott, J. C., \& Gliddon, G., (1855). Types of mankind; or, ethnological researches: Based upon the ancient monuments, paintings, sculptures, and crania of races, and upon their natural, geographical, philological, and biblical history. Philadelphia, PA: Lippincott, Grambo. 
Obenga, T. (2002). Thales of Miletus and Egypt. In M. K. Asante, \& A. Mazama (Ed.), Egypt vs. Greece and the American academy (pp. 165-179). Chicago, IL.: African American Images.

Popper, K. (1957). Poverty of historicism. New York, NY: Routledge.

Ravitch, D. (Summer, 1990). Multiculturalism: E pluribus plures. The American Scholar, 59(3), 337-354.

Said, E. W. (1978). Orientalism. New York, NY: Vintage.

Sénghor, L. S. (1992). Letter to Valentine Y. Mudimbe. In V. Y. Mudimbe (Ed.), The surreptitious speech: Présence Africainé and the politics of otherness 1947-1987 (pp. xi-xii). Chicago, IL: University of Chicago.

Stewart, E. C., \& Bennett, M. J. (1991). American cultural patterns: A cross-cultural perspective. Boston, MA: Intercultural Press.

Welsh-Asante, K. (1993). The Aesthetic conceptualization of Nzuri. In K. W. Asante (Ed.), The African aesthetic: Keeper of the traditions (pp. 7-9). Westport, CT: Greenwood Press. 